\title{
Collaborative Innovation Strategies on Poverty Relief Through Tourism and Cultural Heritage Protection-Based on Case Study in Sichuan Ethnic Regions
}

\author{
Qian-bing DUAN, Ping HUANG*, Zi-zhong YIN, Jian YUE and Fei ZHAN \\ School of Management, Chengdu University of Information Technology, Chengdu, China \\ ${ }^{*}$ Corresponding author
}

\begin{abstract}
Keywords: Ethnic Region; Poverty Relief Through Tourism; Cultural Heritage Management; Innovative Endogenous Mechanism; Sichuan.

Abstract. Poverty relief through tourism has been recognized as an effective way of industrial poverty alleviation around the globe. It is also the poverty relief method with an early start, and numerous, influential as well as long-lasting impacts. Since 1990s, poverty relief through tourism in Sichuan Province has achieved considerable results. However, plans for cultural protection is short-handed in the first place, and in particular, the hallowing villages caused by urbanization has not only brought difficulties to the inheritance of national culture, but also raised cultural amnesia. Therefore, it is of great importance to find out a sustainable methods, based on theoretical and practical experience both home and abroad with Chinese characteristics, to protect culture through poverty relief tourism and the other way around, so as to build up an innovation endogenous mechanism combining tourism development and cultural heritage management.
\end{abstract}

\section{Introduction}

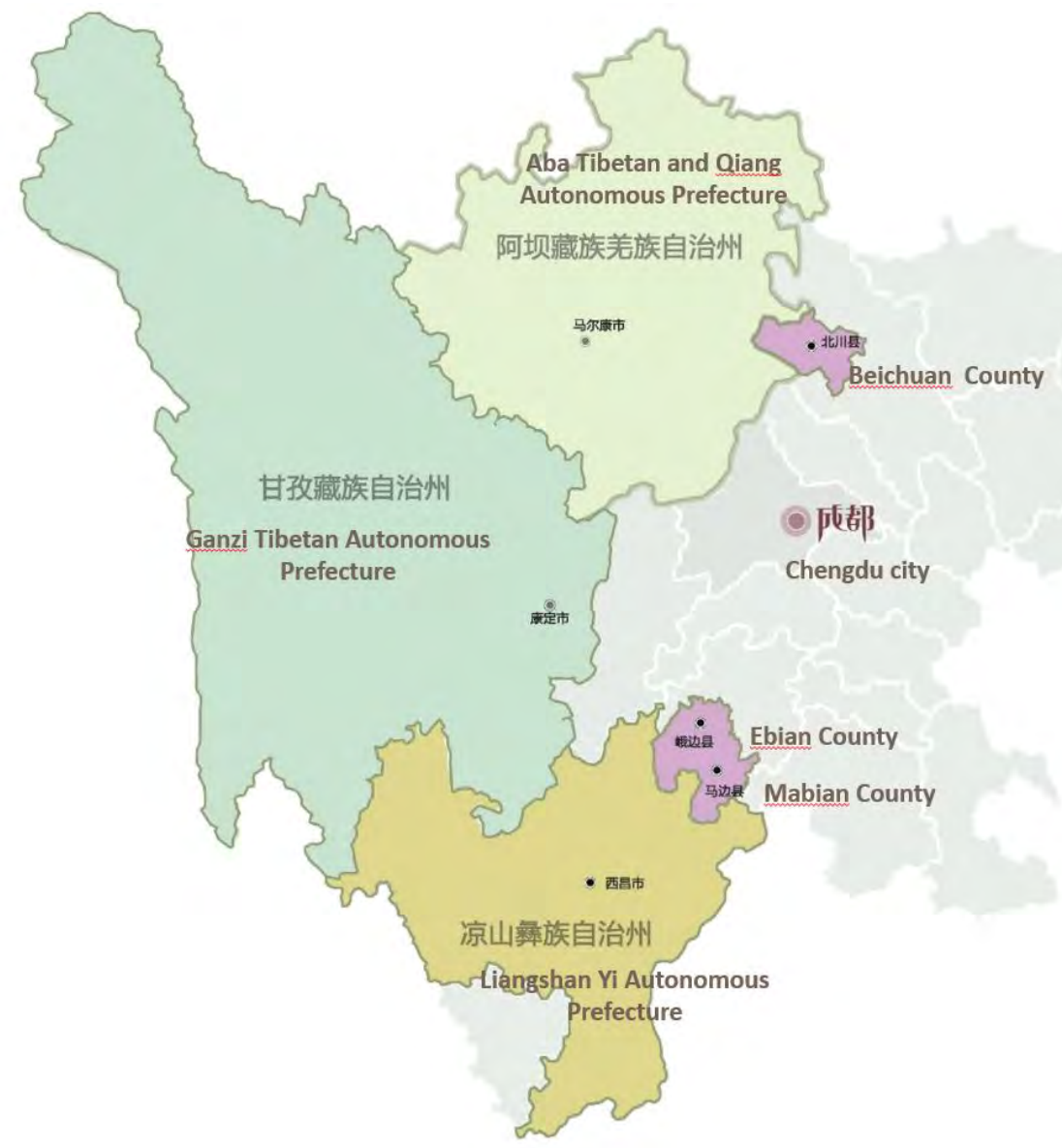

Figure 1. The Map of Three Counties and Three Counties in Sichuan Ethnic Region 
Covering 305,000 square kilometers, ethnic areas in Sichuan take up $62.9 \%$ of the whole province, including A'ba county, Liangshan county, Ganzi county, Mabian county, E'bian county and Beichuan county. (Fig. 1) With a population of 7.056 million( $7.8 \%$ of the province), it's now the largest dwelling place of Yizu Minority ethnic group, the second largest of Tibetan ethnic group, and the one and the only inhabitant region of Qiangzu ethnic group in China. What's more, being a national key eco functional zone and upper-stream Yangtze River eco reservation area, it is confronted with numerous problems in the battle against poverty. Governments of all levels in Sichuan Province are forced to deal with practical situations in this new era, to overcome overpopulated, in-depth, high rate, and recurring difficulties in poverty relief. Since 1990s, a tourism poverty relief campaign has been launched out through Sichuan. Through years of efforts, many poverty-stricken ethnic villages have shown brand new situations with rich and beautiful environment, however, as a result of over concentration on income-poverty, ethnic cultures in these areas have been somewhat undermined to certain extents, or even threatened by cultural amnesia. [1] Theoretically, there's no conflict between cultural tourism and cultural protection, while practically, innovative models of poverty relief through tourism and management mechanism of cultural protection are in highly urgent demand. Only in this way, a sustainable collaborative relationship between these two aspects can been organically built up.

\section{Definition of Poverty Relief through Tourism}

Global concepts about poverty relief through tourism mainly include PPT and ST-EP. PPT, full name Pro-Poor Tourism, has been defined as "Tourism that beneficial to the development of poverty-stricken people". [2] Brought up by DFID of the UK in April 1999, PPT is not a special type of tourism product, but a method for tourism development, which focuses on helping poor population to get more opportunities and net income during their engagement in tourism development. In 2000, DFID set up a tourism challenge foundation to support pilot projects of PPT, and it's now being tested by implementation in UK, Europe as well as other areas and countries around the globe.

Another concept is ST-EP (Sustainable Tourism as an effective tool for Eliminating Poverty). It made its debut in the UNWTO World Summit on Sustainable Development in Johannesburg August 2002, being called the Sustainable Project for Eliminating Poverty through Tourism. Although there's no complete definition for ST-EP in UNWTO, neither a standard set of rule, programs and modes, it's now been regarding as a beacon for many key international agencies and countries in the great course of international poverty alleviation.

In China, Poverty Relief through Tourism has been taken as a well acknowledged and widely adopted concept among government, academics and social communities. Compared with its international counterparts like PPT and ST-EP, the concept in China includes at least three definitions. First, the target people of poverty alleviation are those lived in poverty-stricken areas, and in order to achieve permanent poverty-free, its core value is to improve income from tourism by providing more opportunities and promoting their ambition and wisdom. [3] Secondly, poverty relief is a method based on tourism development, (Liu Jian, 2006) which should be equally supported by interest parties under the principals of cooperative negotiation, mutual benefit and win-win result, including government, non-government organizations (including international aid agencies), communities (individual and organization), and enterprises etc., and should be carried out with adjustable measures in accordance with different situations and diversified development patterns. Thirdly, the ultimate goal is to achieve a five-in-on sustainable development among politics, economy, society, culture and eco-environment. [4]

\section{Conflicts: Alleviating Poverty through Tourism and Cultural Protection}

Under the national strategic framework, the development of new villages became an important approach in poverty relief in Sichuan. For example, projects like "ten poverty alleviation projects" in Yi ethnic villages and "six people's livelihood projects" for Tibetan new villages in Sichuan, all 
make a contribution in alleviating poverty-stricken population in Sichuan ethnic regions. [5] However, facts from village tourism in these areas reveal two problems. On the one hand, the concept and target of poverty relief focus much more on merely increasing income rather than comprehensive improvement. On the other hand, measures adopted in the development process fall to match the management mechanism in cultural heritage protection. In that case, conflicts between poverty relief and cultural heritage protection are commonly seen in ethnic villages, which be seen from the following two typical aspects.

Firstly, the ideal balance between protective development and cultural heritage protection is hard to achieve. Take the Taoping Qiang village for example. Located in Lixian County, Aba Prefecture, it has been attracting more and more tourists since its development in 1996. [6] In order to meet the demand of increasing visitors, a few rich villagers began to build up new houses by themselves, which not only broke the balance of added value per capita that earned from tourism development, but also brought the architectural culture of the old town under overload threat. To help villagers get higher income and improve tourism development of cultural heritage, the local government brought in investment from outside companies in 2006 and planned a brand-new town that duplicated the old style by adopting the model of "company plus local household". While newly built houses suffered terribly from the Wenchuan earthquake, thus the government took some measures including giving reinforcement allowance to stricken houses on a standard of 600 yuan per square meter (for decorated houses) and 500 yuan per square meter (for the undecorated), providing 8 -year-period 20,000 yuan low-interest tourism loans for each family, and assisting infrastructure construction with a standard of 3500 yuan per square meter. Since most of the villagers moved to the new town and began to live and take tourism business there, the conflicts between tourism development and cultural protection became increasingly prominent among different beneficiary. It is because all the cultural sites that attract visitors in Taoping are all located in the old town, such as the "most mysterious oriental castles", "the living fossil of Qiang ethnic art of architecture", and "the world Qiang cultural heritage". Since 2013, the travel agencies designated by government took the entrance ticket management of the old town in charge and $25 \%$ of the total incomes were allocated to the Taoping village committee, with a redistribution of $60 \%$ and $40 \%$ to the construction area and its population respectively, and the rest money spared for daily administration and old town protection. However, with the over emphasis on economic growth under poverty relief through tourism, the conflicts between cultural tradition protection brought by government and economic benefits pursued by local people are inevitable. According to the survey, the government tries to protect Qiang culture through language training class, museum and local art group of Qiang culture, while it turns out that the intangible cultural heritage is at high risk of distinction as a result of the villagers being occupied with tourism reception. In the local art group, more than $80 \%$ are middle aged ladies, and only 38\% villagers celebrate their Qiang traditional festivals and 30.9\% consider singing and dancing to the Qiang music is an emotional carrier, while $36 \%$ say they only wear Qiang costumes on important festivals or having tourists at their homes. As culture has been displayed commercially, the dynamic culture of ethnic groups begins to fade away.

Secondly, the cultural filtering leads to the distinction of its origin. Cultural filtering refers to the phenomenon that decision makers only chose some cultural symbols attractive to visitors more for the purpose of business like touring and experiencing, causing a distortion or even distinction of its cultural essence. For example, Jiaju Tibetan village in the Danba County of Ganzi Prefecture has become a very attractive tourist resource for the outside world. In 2005, it was selected as by Chinese National Geographic magazine as "the most beautiful country town in China". Since 2000, the tourism development began to flourish and, in the process, the local government plays the role of the training of the demonstration households in the Jiaju Tibetan village and the management of scenic spot tickets, which basically dominates the direction of village tourism development. Of course, at the same time, the government has repeatedly stressed that the Tibetan architectural style is a kind of treasurable resources and strived to control the changes in the style of the residential buildings in the village. While in order to meet the demand for large number of tourists, some local families used non-traditional methods to rebuild and build up new houses, and some of them even 
changed the farming land into parking lots without authorization, which to some extent destroyed the overall traditional style of the Tibetan village. However, under the intervention of the government, the village has generally maintained its original architectural style. In addition, the Danba Beauty Valley is well-known both at home and abroad, and the beauty of the costumes is also a big attraction of the Jiaju Tibetan Village. However, before the development of tourism, residents there usually dressed in national costumes during festivals, while nowadays, in order to welcome tourists, they wear costumes every day. Some young people that study and work outside are used to change onto their ethnic costumes once returning to the village, which not only enhanced the attraction to domestic and foreign tourists, but also in turn strengthened the sense of pride of the villagers. Therefore, when many Tibetan areas in Sichuan were irreversibly losing the traditional culture during modernization, the cultural elements here, such as architecture and costumes, were relatively well preserved. However, it is unavoidable that some cultural matters that have been filtered out in tourism development have experienced variations in recession and extinction. Due to the limitation of reception capacity in the village, about $40 \%$ of the households still do not open to the visitors, but only participate in the ticket profit dividends, while the 19 "demonstration households in tourism reception" received high incomes. It can be seen that the tourism industry has brought more income to the poverty-stricken areas, and at the same time also caused income gap between the communities and between the rich and the poor, which has led to conflicts between the neighborhoods. For example, the "Three Sisters" inn is the largest residential demonstration model in the village. It was once involved in a conflict that tourists in their house jumped to the late at night, which bothered the neighbors from rest, and brought in the police. What's more, in order to get tourists as many as possible, residents usually leave a bad impression and also create various unpleasant disputes and so on. The close interpersonal cooperation and interpersonal relationship of the village communities formed under the traditional lifestyle gradually disappeared, being replaced by the conflict of interest competition in tourism development.
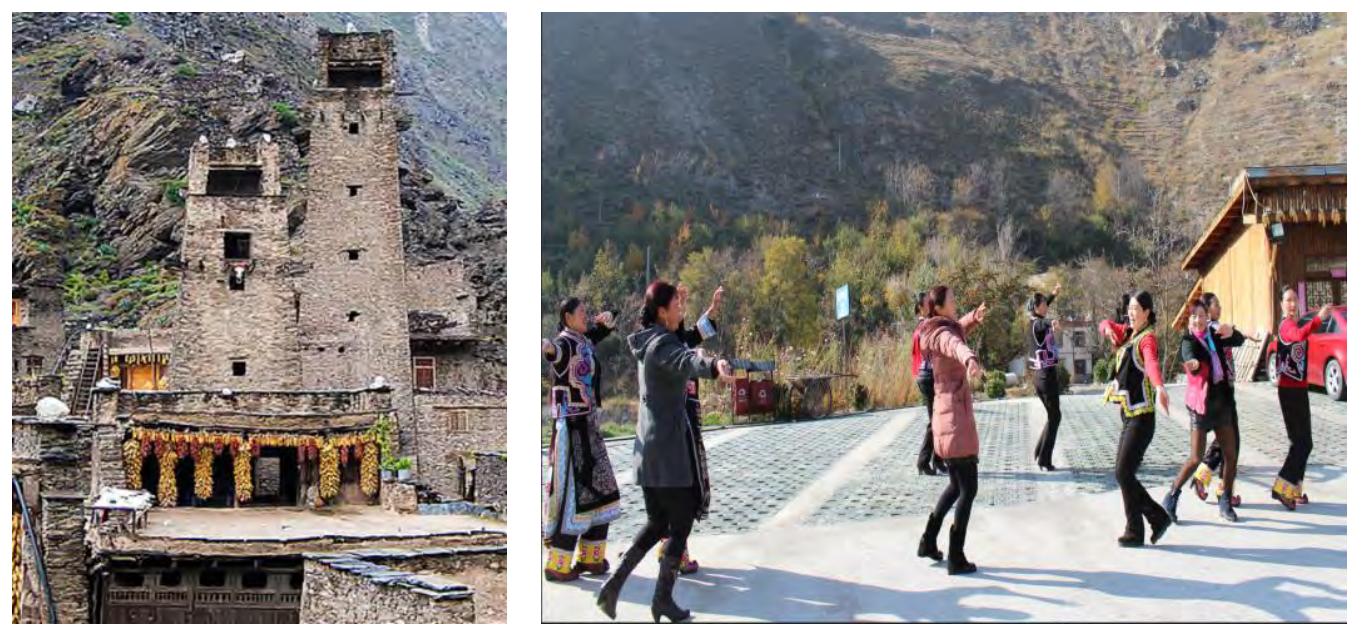

Figure 2. The "Old Village" and "The Local Wind Singing and Dancing Troupe" in the Qiangping Village of Peach Ping

\section{Collaborative Innovation Strategies}

The combination of tourism poverty alleviation and cultural protection is an effective way to ensure the persistence of tourism poverty alleviation and increase the self-development ability of poverty-stricken areas. It is necessary to incorporate cultural heritage management into timely "replenishment":

First, participate in the determination and management of cultural heritage value and cultural tourism. "Entertainment is the 'honey' that makes learning and culture the "pill"" [7]. For any visitor who enters the ethnic village for the first time, if they can make the tourists more accessible to the cultural tourism products and enjoy the pleasure experience, they can reduce the tourists' 
strangeness to the culture and encourage them to have a strong interest in the visiting culture. Of course, to achieve such an effect, it is necessary for the tourism management department and the cultural management department to work closely together, not only to cooperate on the value exploration of cultural heritage, but also to jointly select demonstrations that are acceptable to tourists. From the successful cases at home and abroad, the storytelling and the expression of songs and dances, folk festivals, games, cultural products, guided tours, physical sitcoms, museums, etc. are the most direct and effective ways to attract tourists to experience the culture. If the excavation of the cultural heritage in the ethnic villages is profound enough, the storyline of the exhibition will be attractive, and the cultural heritage value will be more abundant and vivid, and the opportunities for tourists to enjoy the pleasure experience will increase. In turn, in order to meet the needs of those who need higher quality and experience, the tourism management department will pay more attention to the protection of cultural heritage values and the authenticity of tourism products, so they will actively propose to the cultural heritage management department. As a result, cultural tourism and cultural heritage management will inevitably move towards a close and cooperative state of circular interaction.

Second, it is responsible for providing cultural tourism with effective information of cultural heritage dissemination. The so-called effective dissemination of cultural heritage means that the transmitted cultural heritage information is the information that tourism consumers need, otherwise the transmission of information will be invalid. From the perspective of the practice of poverty alleviation in ethnic villages, the use of cultural heritage is mostly limited to its external value as a cultural symbol of tourism attraction. It does not excavate the cultural core values in a deeper sense, neither explores values and outlook on the world and life, which often results in relatively simple content and form, similarities and shallow meanings of cultural heritage in the same region and the same ethnic group. That is the problem of cultural commodification, stage and vulgarization that often criticized by the academic community. It is true that most tourists participate in cultural tourism mainly for the purpose of seeking temporary relaxation and pleasure, but for some experienced tourists, they need more "authentic" cultural tourism products. The authenticity referred to here is not completely equivalent to reality. It can be said that there are three basic characteristics that the real and effective information provided by cultural heritage needs to have: one is related to the expectations of tourists and conforms to the imagination of tourists; the other is belonging to local ethnic groups, a unique hereditary life style that substantially affects the survival and development of local people, not a purely commercial performance; the third is to have customers accessible to consumption and feel interesting, relaxed and happy. Therefore, cultural tourism requires the cultural heritage management department to guide the content and delivery of cultural heritage information. As long as the information that consumers are willing to accept, it may produce effective communication results, which is also an important feature of cultural tourism with strong vitality.

Third, establish a cultural heritage risk assessment mechanism. For the precious ethnic cultural heritage, the management department must insist on putting protection first and taking on the responsibility. First, learn from the management model of nature reserves in China and strengthen the establishment and management of "historical and cultural protection zones" in ethnic areas. The core areas, buffer zones and open areas of cultural protected areas can be sorted out according to the resources. The core area strictly controls the number of foreign visitors, and is only available for scientific research, field observation and concerned activities; the buffer zone can provide limited appointments for visits, education and learning activities; the open area can be used as a tourist poverty alleviation target and open to tourists. Second, the cultural heritage management department has one veto power in the selection of tourism poverty alleviation villages in the open area; the third is to establish a cultural protection compensation mechanism, that is, for the ethnic villages in the core area and the buffer zone, different standards of cultural heritage protection compensation will be granted annually, including opportunity cost compensation, cultural inheritance and restoration compensation, production technology protection compensation, ecological protection compensation, etc., to ensure that the contribution of ethnic cultural protection 
in these areas is compensated reasonably; the fourth, strengthen the early warning and control management of cultural amnesia risk in cultural protection areas, set levels of cultural heritage risk for the implementation of the annual risk assessment and verification system; the fifth, for ethnic villages open to tourism reception, management department should carry out cultural protection plans to ensure the protection and promotion of ethnic cultural characteristics

Fourth, build up a cooperative relationship. Stakeholders in tourism poverty alleviation mainly include 5 types, government, tourism enterprises (developers, operators), local communities (community residents and organizations, etc.), pressure groups (environmental protection, cultural protection, human rights and other non-governmental organizations and media, research institutes, social followers), and tourists. They are both dependent and contradictory. Only by moving toward "collaboration" is the management focus of achieving the balance between stakeholders. Of course, the key is to effectively identify the "interests" of stakeholders. To begin with, in the decision-making and development process of tourism poverty alleviation, to participate in the identification of stakeholders in advance,[8] determine who has legitimate interests in the development and management of cultural heritage, and conduct in-depth and comprehensive understanding of the interests of stakeholders, and to provide consulting services for stakeholders in terms of coordinating interests; secondly, on the condition of ensuring core values integrity of cultural heritage, to fully understand the interests of tourism development, and provide cultural heritage attractive to tourists as much as possible and to help management departments to better display cultural tourism products from the perspective of maximizing the satisfaction of visitors' cultural experience; third, guide stakeholders to cherish the cultural heritage and make them be aware of the fact that cultural heritage resources are indispensable for their tourism economic interests, thus encouraging stakeholders to voluntarily use part of tourism revenue as cultural heritage protection fund, supporting and participating in cultural heritage protection with assumed obligations.

Fifth, strengthen the construction of the legal system for cultural heritage management. Since the establishment of China, legal system in the protection of cultural relics formed initially, and the protection of villages, ethnic and folk cultures are all included. In 2011, the Intangible Heritage Law is issued, which provides an important legal basis for the management of the inheritance, protection and preservation of intangible cultural heritage. However, being pushed forward by government's policy of poverty alleviation through tourism, the cultural heritage management of ethnic villages is encountered with great challenges, and it is necessary to refer to regulations from a legal perspective. First, it is necessary to formulate the "Measures for the Management of Poverty Alleviation in Ethnic Villages", to clarify the dominant status of cultural heritage management departments in the use of cultural heritage in tourism poverty alleviation; second, it is necessary to prepare "Ethnic cultural Heritage Accreditation Standards", with reference to international conventions and laws and regulations such as the Intangible Heritage Law and the Cultural Relics Protection Law. What's more, based on its nature and characters, to establish a standard of accreditation with Chinese characteristics to promote the standardization and precision of cultural heritage protection management; third, the Intellectual Property Rights and Civil Protection Regulations of Ethnic and Folk Traditional Culture is important to guarantee the legitimate rights and interests of cultural heritage right holders and hereby to promote the inheritance and protection of cultural heritage.

\section{Conclusion}

Poverty is not only a shortage of social material life, but also a comprehensive phenomenon of material and spiritual life in the society, which has a close relationship between the institutional arrangements of social resource allocation and consumption, the interaction between individuals and groups, as well as people's ideas and feelings about life [9]. Therefore, tourism-led poverty alleviation should not only target at material poverty alleviation, but also poverty alleviation on spiritual and thoughts. It should be acknowledged that for those ethnic villages entered the tourism market earlier, a considerable number of community members has changed their ideas on the 
market concept and gradually became capable in realizing economic benefits independently. This part of the staff and some local officers realized that culture heritage is the core of tourism value in ethnic villages, and it's the important capital supporting the survival and development of the ethnic group, so they begin to seek a balance between cultural tourism and cultural heritage management in practice. However, in the context of poverty and modernization, it is indeed not easy to achieve synergy between tourism poverty alleviation and cultural heritage management. Of course, the timely "replenishment" of cultural heritage management is the right way to solve the sustainable zero-sum game between tourism development and cultural heritage management in ethnic areas for the purpose of poverty alleviation.

\section{References}

[1] Jane Jacobs. Dark Age Ahead [M]. New York: Random House USA Inc (Reprint edition), 2005.

[2] Wang Zhaofeng. Research on poverty relief through tourism in minority regions [M]. Beijing: China Social Sciences Publishing house, 2011:97-106

[3] Huang Chengwei, Wang Jianming. Ethnic minorities and the development of poverty alleviation [M]. Beijing: The Ethnic Publishing house, 2011:2-3

[4] Huang Ping. Embarrassment and method: a research on administration of southwest minority village cultural heritage under the perspective of tourism poverty alleviation [J]. Qinghai Journal of Ethnology, 2015 (1): 14-19

[5] Zhang Qi, Wang Jianming etc. The mode of entire village poverty relief and the development of minority social community [M]. Beijing: The Ethnic Publishing house, 2013: 182-208

[6] Huang Ping, Wang Yuanlong. The study on the sustainable development model of Sichuan minority culture ecotourism [J]. Southwest Minzu University, Humanities \& Social Sciences 26. 8, 2005, 177-180.

[7] Bob McKercher, Hilary du Cros. Cultural Tourism: The Partnership between Tourism and Cultural Heritage Management. Haworth Hospitality Press, 2002.

[8] Howard White. The Measurement of Poverty [A]. In Vandana Desai and Robert Potter eds. The Companion to Development Studies. London: Amold Press, 2002: 32-35.

[9] George, Henry. Progress and poverty [M]. New York: Cosimo Classics, 2006. 